\title{
The 'Negro' in John Steinbecks OfMice and Men: A Comparison of Socialist and Post-Socialist Strategies for Translating Racial Elements
}

\begin{abstract}
The present article examines the translation of racial elements in John Steinbeck's novel and play $O f$ Mice and Men into Slovenian. Using the basic concepts of Kitty van Leuven-Zwart's comparative and descriptive models for the analysis of literary translations (1989, 1990), we examine strategies for translating terms referring to African Americans along with strategies for translating the discourse of the only African American character in Of Mice and Men. After the microstructural analysis, the effects of the shifts on the perception of this literary work are discussed, and its reception in Slovenia is examined. Although shifts are established in translations from both the socialist and the postsocialist period, in the first translation of the novel, from 1952, the macrostructure of the text was affected to a greater extent than in the modern translations of the novel and the play, both published in 2007. Because translation strategies differ substantially, possible reasons for the differences are also discussed, taking into consideration relevant historical and contemporary socio-political factors.
\end{abstract}

Keywords: translation; shifts; racism; John Steinbeck; Of Mice and Men

\section{"Zamorec" v delu OfMice and Men Johna Steinbecka: Primerjava socialističnih in postsocialističnih strategij za prevajanje rasnih elementov}

POVZETEK

Pričujoči članek obravnava prevajanje rasnih elementov v slovenskih prevodih Steinbeckovega romana in drame Of Mice and Men.S pomočjo temeljnih konceptov primerjalnega in opisnega modela Kitty van Leuven-Zwart za analizo književnih prevodov $(1989,1990)$ obravnavamo tako strategije za prevajanje poimenovanj za Afroameričane kot tudi strategije za prevajanje diskurza edine afroameriške pripovedne osebe v Of Mice and Men. Po mikrostrukturni analizi ugotavljamo učinke premikov na percepcijo tega literarnega dela in na njegovo recepcijo v Sloveniji. Ceprav smo premike ugotovili tako $\mathrm{v}$ prevodu iz socialističnega obdobja kot tudi v prevodih iz postsocialističnega obdobja, so v prvem prevodu romana iz leta 1952 na makrostrukturo besedila vplivali v večji meri kot $\mathrm{v}$ modernih prevodih romana in drame iz leta 2007. Ker so se prevajalske strategije bistveno razlikovale, obravnavamo tudi potencialne razloge za razlike, pri čemer upoštevamo relevantne zgodovinske in socio-politične dejavnike.

Ključne besede: prevajanje; premiki; rasizem; John Steinbeck; Of Mice and Men 


\section{The 'Negro' in John Steinbecks OfMice and Men: A Comparison of Socialist and Post-Socialist Strategies for Translating Racial Elements ${ }^{1}$}

\section{Introduction}

While translation was once regarded as a purely linguistic process, in recent decades numerous scholars (see, for instance, Lefevere 1992; Venuti 1998; Hermans 1999) have argued that the process of translation is to some extent determined by dominant norms and ideology. Slovenia is no exception; research has shown that especially during the period of socialism (1945-1991) translation of literary works was influenced by contemporary ideology (see, for instance, Orel Kos 2001; Kocijančič Pokorn 2008, 2010, 2012; Svetina 2009; Mazi-Leskovar 2011). The present article is concerned with the question of whether and how Slovenian attitudes towards racism influenced translation.

The issue of racism towards African Americans in works of fiction has received considerable attention in the USA, while the same cannot be said of Slovenian translations of those works which were challenged in the source culture because they were perceived as racist. One such example is Of Mice and Men, in which John Steinbeck portrayed the life of farm workers during the Great Depression. While the plot primarily revolves around the struggles of the migrant workers George and Lennie, the racism faced by the African American 'stable buck' Crooks is also addressed. Upon publication in 1937, both the novel and the play of the same name were received favourably by the critics and the general public (Čerče 2006, 68). In recent decades, however, Of Mice and Men has frequently been challenged because of its alleged racism (Foerstel 2002, 277; Sova 2006, 23940; Hinds 2008, 9). By analysing strategies for translating racial elements in the two Slovenian translations of this novel and the translation of the play, we aim to show how changes with regard to the severity of racist discourse may alter readers' perception of certain aspects of a literary work, and thus have some effect on its status in a literary system.

\section{Methodology}

An adapted version of van Leuven-Zwart's comparative and descriptive models (1989, 155-81; cf. Lambert and van Gorp 2006, 46-47) is used for the analysis of the texts; the original and the translations are first compared on the microstructural level (the phrase, clause, and sentence level); subsequently, the effects of the microstructural shifts ${ }^{2}$ on the macrostructure (for instance, the reader's perception of the characters and the relationships between characters) of the text are described. Although van Leuven-Zwart differentiates between three main categories of shifts (modulations, modifications and mutations) with numerous subcategories (see 1990, 87), only the following categories are relevant for the present analysis (see 1990, 72-73, 80-81, 86):

- stylistic modulation involving register - neutral translation of a marked term, for instance, translating the pejorative English term 'nigger' with the neutral Slovenian term denoting a black person írnec (black);

This article is based on the author's PhD thesis (Trupej 2013), University of Ljubljana.

In translation studies, shifts are most commonly defined as "changes which occur or may occur in the process of translating" (Bakker, Koster, and van Leuven-Zwart 2009, 269). One of the first definitions was provided in 1970 by Anton Popovič: "All that appears as new with respect to the original, or fails to appear where it might have been expected, may be interpreted as a shift" (quoted in Bakker, Koster, and van Leuven-Zwart 2009, 271). 
- $\quad$ syntactic-semantic modification involving grammatical classes - for instance, replacing a noun from the original with a pronoun in the translation;

- $\quad$ mutation - radical change of meaning, addition, deletion.

In addition to discussing the macrostructural effects of the identified shifts, we look at the Slovenian critical response to Of Mice and Men in order to establish whether and how the shifts affected its reception in the literary system of the target culture. We also discuss the possible reasons for the identified translation strategies, since, as Kirsten Malmkjaer notes, while some shifts occur because of the translator's insufficient knowledge of the source language or can be categorised as mistakes (2004, 149-54; cf. Lambert and van Gorp 2006, 43), many shifts are motivated and made consciously, in order for the translation to conform to norms in the target culture (Malmkjaer 2004, 142-43).

\section{Comparison of English and Slovenian Terminology for Black People}

In the USA, the attitudes towards several terms used for denoting African Americans have changed significantly throughout history. The term 'nigger' is widely considered one of the most offensive words in the modern English language (Hill 2008, 51; see also Battistella 2005, 75; Rattansi 2007, 120; Asim 2007, 9), and while its use was not always deemed as unacceptable as it is today, the term was pejorative by the time Steinbeck wrote Of Mice and Men (see Kennedy 2003, 4-5; Asim 2007, 11; Hill 2008, 51). In the 1930s, 'negro' and 'colored' were still neutral terms, although they would later also become pejorative, and thus replaced by 'black' and 'African American' (see Rattansi 2007, 116).

The historical development of corresponding Slovenian terminology can be established by analysing how and how frequently selected terms referring to black people were used during different periods, examining their frequency in Slovenian printed media available in the corpus of the Digital Library of Slovenia (2014). The results, together with an analysis of the contexts as well as dictionary entries, show that in the pre-World War II decades the terms zamorec and crnec were used with similar frequency. ${ }^{3}$ After the war crmec developed into the standard term, while zamorec began to be perceived as pejorative and was thus used less frequently. ${ }^{4}$ In the post-socialist period, another shift in terminology is evident; while the term crmec is still widely used, in the new millennium temnopolt replaced it as the most 'politically correct' term (see Trupej 2014c, 638-39; Prešern 2001).

To further establish modern attitudes towards racial terminology a survey was carried out. In one part of the questionnaire, ${ }^{5}$ the 309 respondents graded selected terms with numbers from 1 to 5 the higher the number, the more offensive the term. The medians are as follows: temnopolt (1.17), črnec (1.87), črnokožec (3.13), zamorec (3.22), zamurc (3.83), črnuh 6 (4.46), črnuhar (4.58), črnavs (4.61). The microstructural examination of the translations is based on these findings.?

While črnec is derived from črn (black), the term zamorec denotes somebody from behind the sea ("Narodski običaji v Železnikah" 1854, 100; "Izlet iz Gorice v Tržaško okolico" 1885, 2; Pogačnik 1981, 172).

4 In texts digitalised up to 1 September 2014, zamorec was used at least once in 11,511 and črnec in 9,828 publications from 1919 to 1945, while in the period between 1946 and 1991 zamorec was used at least once in 953 and crmec in 2,660 publications.

The full text of the survey can be accessed at: https://docs.google.com/spreadsheet/viewform?formkey=dEViZm5rX2ZxRzI2W VFOOFRDVVhQWkE6MQ.

6 Crnuh is the most frequently used offensive Slovenian term for a black person and has been derogatory since at least the latter part of the 19th century (see Pleteršnik 1894, 114).

For more details regarding Slovenian terminology see Trupej (2013; 2014b; 2014c).

PART II: Intercultural Landscapes 


\section{Analysis of the Translations}

\subsection{Preliminary Information}

Maurene J. Hinds notes that the frequent use of the term 'nigger' is one of the main reasons why $O f$ Mice and Men is problematic to modern readers, although she is of the opinion that in this novel Steinbeck wished to address the unacceptability of racism $(2008,116-17,122-23$; see also Sova 2006, 239). ${ }^{8}$ While the 16 occurrences of 'nigger' in the novel were less problematic at the time of its initial publication than they are today, the fact that this term is never uttered in the 1939 movie of the same name indicates that even then its presence was a somewhat delicate issue. In our analysis we focus especially on the translation strategies for this racial slur, while also taking the terms 'negro', 'colored' and 'black' into consideration - for the purpose of comparing translation strategies.

The translation is evaluated on the following basis: if at the time of the publication of the original text a certain term was considered neutral/offensive, and at the time of the translation's publication a corresponding neutral/offensive Slovenian term was used, this does not constitute a shift. If this is not the case, shifts are identified and categorised. Also examined are translation strategies for the discourse of the only African American character in the novel, by the name of Crooks.

\subsection{Ljudje in misi (1952, Translated by Meta Gosak) ${ }^{9}$}

\subsubsection{Translation Analysis}

The analysis of this translation shows that shifts occurred in all the instances of the term 'nigger' being used in the original, partly related to the fact that the translation is sometimes only loosely based on the original. Most frequently this term is translated into the neutral noun crmec (black) (Steinbeck [1937] 2006/Steinbeck [Gosak] 1952, 22/25 (3×), 22/26, 32/36, 49/54, 80/87 (3×), $89 / 98,91 / 100,91 / 101,110 / 123)$, which can be classified as a stylistic modulation with respect to register. 'Nigger' is twice replaced with a pronoun (Steinbeck [1937] 2006/Steinbeck [Gosak] 1952, $22 / 25,22 / 26$ ), constituting a syntactic-semantic modification involving grammatical classes. In one instance a deletion occurs; the whole sentence which includes the term remains untranslated (Steinbeck [1937] 2006/Steinbeck [Gosak] 1952, 22/26). All three categories of shifts occur in the conversation between the elderly worker Candy and the newly arrived George, during which the former relates to the latter how the farm workers allowed the African American 'stable buck' Crooks to associate with them for Christmas: ${ }^{10}$

They let the nigger come in that night. Little skinner name of Smitty took after the nigger.

Done pretty good, too. The guys wouldn't let him use his feet, so the nigger got him. If he

8 An overview of Steinbeck's other writings about racial issues supports the view that he had no racist tendencies. He addressed racism in the 1936 short story "The Vigilante," in which he criticised the oppression of African Americans (Werlock 2006, 408-9), and in 1943 he protested against their stereotypical characterisation in the Alfred Hitchcock movie Lifeboat, which was based on a script that Steinbeck had written (Meyer 2006a, 212). Furthermore, in 1960 he wrote two articles about the struggles of African Americans for The Saturday Review, but later refused any further collaboration with this magazine because one of the articles had been edited without his consent (Ouderkirk 2006, 29-30; Meyer 2006b, 17). Steinbeck also voiced his opposition towards racial segregation in the travelogue Travels with Charley (see 1962, 215-42).

$9 \quad$ Finding any relevant biographical data about Meta Gosak proved impossible. However, since her bibliography consists of only two translations (COBISS 2015), it is certain that she was not primarily a literary translator.

10 In the analysis of the texts, bold print is used to emphasise the parts that are compared. The Slovenian translations are followed by a gloss, translated back into English by the author of the present article. Deletions are indicated by the symbol $\varnothing$. 
coulda used his feet, Smitty says he woulda killed the nigger. The guys said on account of the nigger's got a crooked back, Smitty can't use his feet. (Steinbeck [1937] 2006, 22)

Povabili smo tudi črnca. Mali Smitty se je spoprijel z njim. Nihče drug se namreč ni pustil obrcati in zato se je Smitty pač spravil nad črnca. [Ø] Ker se je posluževal v borbi nog, je [Smitty] rekel, da ga bo pobil, toda ker je imel črnec tako že polomljeno hrbtenico, so bili drugi na črnčevi strani in prigovarjali Smittyju, naj se vendar ne spušča v tako neenako borbo. (Steinbeck [Gosak] 1952, 25-26)

[We invited the black guy too. Little Smitty fought him. Nobody else would let himself get kicked, so Smitty took after the black guy. [Ø] Because he used his feet when fighting, he [Smitty] said he'd kill him, but on account of the black guy having a crooked back as it is, the others were on the black guy's side and tried to persuade Smitty not to engage in such an unequal fight.]

While the white characters on the ranch use 'nigger', Crooks most frequently employs 'colored' when referring to his race. For this term, Gosak used both črnec and crrnski (Steinbeck [1937] 2006/Steinbeck [Gosak] 1952, 80/87 (2x), 91/100, 93/103), the Slovenian noun and adjective both meaning 'black'. This will not be classified as a shift, because the original term was neutral at the time of the novel's publication, and the same is true for the Slovenian terms when the translation was published. However, a shift does occur in the one instance when the adjective barvan is used (Steinbeck [1937] 2006/Steinbeck [Gosak] 1952, 85/93); since this Slovenian term does not denote race and can be defined as 'painted' or 'covered with paint', it constitutes a radical change of meaning.

When referring to his race, Crooks also uses the adjective 'black' in three instances, and since Gosak again employed the noun crmec (Steinbeck [1937] 2006/Steinbeck [Gosak] 1952, 77/84 $(2 \times), 82 / 90)$, this is not a shift. The same is true when crnec is the translation for 'negro', which is used by the third person narrator and by Crooks (Steinbeck [1937] 2006/Steinbeck [Gosak] $1952,56 / 62,75 / 82,79 / 87)$, since both terms were neutral at the time when the original and the translation were published. However, in one instance there is no corresponding term for 'negro' in the translation - the translator expanded the latter part of the following sentence, thereby emphasising the issue of racism:

Crooks had retired into the terrible protective dignity of the negro. (Steinbeck [1937] 2006, 89) Crooksov obraz je postal resen in strog, dekle se je dotaknilo njegove ranljive točke - žalila je bila njegovo raso [Ø]. (Steinbeck [Gosak] 1952, 98)

[Crooks' face became serious and severe; the girl had touched upon his weak spot - she had insulted his race [Ø].]

Expanding or otherwise altering Crooks' discourse occurs numerous times in this translation. The most obvious change is the higher register in which he speaks, ${ }^{11}$ as illustrated by the translation of the sentence 'I wonder the old lady don't move 'em someplace else' (Steinbeck [1937] 2006, 78); Gosak used the French word madame for 'old lady' (Steinbeck [Gosak] 1952, 85; cf. Steinbeck [Čerče] 2007b, 67), which constitutes a stylistic modulation with respect to register. Several times Crooks' discourse is also altered by means of mutation. For instance, in the conversation between Lennie and Crooks, the translator radically changed the meaning of the sentence 'A guy needs somebody - to be near him' (Steinbeck [1937] 2006, 82) to convey a feeling deeper than closeness:

\footnotetext{
The transformation of the characters' colloquial language into standard Slovenian is characteristic of this translation (see Čerče
} 2006, 244). 
'Človek rabi nekoga ... nekoga, ki ga ima rad' (A guy needs somebody... Somebody that loves him; Steinbeck [Gosak] 1952, 90; cf. Steinbeck [Čerče] 2007b, 71). Later, Crooks' discourse is altered to an even greater extent:

I seen things out here. I wasn't drunk. I don't know if I was asleep. If some guy was with me, he could tell me I was asleep, an' then it would be all right. (Steinbeck [1937] 2006, 83)

Mnogo stvari sem že videl - in o njih premišljeval, toda ker nimam nikogar, $s$ katerim bi se lahko pogovoril, me to tišči in sem dostikrat nesrečen. V̌̌asih se mi zdi, kakor da bi sanjal, če kaj nenavadnega vidim ali slišim. Če bi imel koga, da bi mi rekel: „Glej prijatelj, vse to je res, ti ne sanjašs, « bi mi bilo tako lepo pri duši. (Steinbeck [Gosak] 1952, 90-91; cf. Steinbeck [Čerče] 2007b, 71)

[I've seen many things, and thought about them, but because I have no one to talk to, this lies heavy on me and often I'm miserable. Sometimes I think I'm dreaming if I see or hear something unusual. If I had someone to tell me: "Look, friend, it's all true, you're not dreaming," it would make my soul so happy.]

A similar expansion of this character's discourse was identified in the continuation of the conversation, when Crooks expresses his doubts that a simple farm worker can ever own a piece of land:

I seen guys nearly crazy with loneliness for land, but ever' time a whore house or a blackjack game took what it takes. (Steinbeck [1937] 2006, 86)

Videl sem že mnogo takih, ki so postali skoraj blazni, ker niso imeli nikogar, da bi se lahko pomenili z njim. Želeli so si zemlje, toda ko so imeli denar, so ga zapravili v mestu z ženskami ali pa s pijančevanjem. (Steinbeck [Gosak] 1952, 95; cf. Steinbeck [Čerče] 2007b, 74)

[I've seen many who almost went crazy because they had no one to talk to. They wanted land, but when they had money they spent it in the city on women or drinking.]

Expanding characters' discourse is otherwise not characteristic of this novel; Danica Čerče has identified numerous instances of discourse being simplified or even deleted, while she does not mention any additions (see 2006, 244-47). Thus, the translation strategy for the only African American character seems to have been an exception, and because of it he is featured more prominently in the translation.

\subsubsection{Reception}

According to the bibliography maintained by the Research Centre of the Slovenian Academy of Arts and Sciences, Steinbeck's name appeared in Slovenian print for the very first time in the newspaper Jutro, where Of Mice and Men was named as one of only two American works of fiction published in 1937 worth mentioning (G. K. 1938, 9). Although this novel was not translated until 1952, Slovenian moviegoers had a chance to get acquainted with its plot when the 1939 movie of the same name was shown in Slovenian cinemas in the late 1940s. An anonymous reviewer in Celjski tednik praised the movie because it allegedly painted a real picture of the United States and portrayed it as a country where the working class is ruthlessly exploited. However, he perceived the protagonists' "striving for property, the wish to settle in smalltownish comfort with rabbits, puppies, cows and calves" 12 as a threat to socialist ideology, since it represented the values of the bourgeoisie ("Miši in ljudje’ in še kaj” 1948, 6). A similar sentiment was expressed by Djurdjica

12 Slovenian: "težnja za lastnino, želja po ureditvi lastnega malomeščanskega ugodja, z zajčki, psički, kravicami in telički." 
Flere, who described Of Mice and Men as a "poorly dramatized novel about a fatal weakness and dependency of man - the individual"13 $(1948,877)$.

In 1948, the Slovenian branch of Agitprop placed the novel on the list of works that were not to be translated/published (Gabrič 2008, 67). Taking these criticisms into consideration, we can presume that $O f$ Mice and Men was banned not because of its display of racism, but because certain aspects of it - especially the striving for private property - were seen as unsuitable for audiences in the newly established socialist state.

After the government's grip on the publishing houses loosened somewhat in the early 1950s (see Pirjevec 2011, 338-39), Of Mice and Men was the first of Steinbeck's works to be translated in the post-war period, and only the second overall. Most reviews of it were short, and the issue of racism is not mentioned in any of them (see "Mala knjižica" 1951, 303; b 1952, 4; "John Ernst Steinbeck" 1952, 3; "Novosti našega knjižnega trga" 1952, 9; Skušek 1952, 7); the reviewers focus on George and Lennie, and link their struggles to the problem of the exploitation of the working class. ${ }^{14}$ Commenting upon Gosak's translation, Čerče writes that it is the worst of all Slovenian translations of Steinbeck (2006, 244; cf. Čerče 2011, 37), and substantiates her statement by providing examples, but does not include any shifts regarding racist discourse (2006, 244-47; cf. Čerče 2011, 37-40).

\section{$4.3 O$ miših in ljudeh (2007b, translated by Danica Čerče $)^{15}$ and Ljudje in misi (2007a, translated by Tina Mahkota) ${ }^{16}$}

\subsubsection{Translation Analysis}

In the retranslation of the novel, the term 'nigger' is translated as zamorc (a colloquial variant of zamorec) in eleven instances (Steinbeck [1937] 2006/Steinbeck [Čerče] 2007b, 22/23 (3x), 22/24 $(2 \times), 32 / 31,49 / 45,89 / 76,91 / 77,91 / 78,110 / 93)$. Although it was established in the survey that the majority of Slovenians consider this term to be pejorative to some extent, it is not the most offensive Slovenian term that can be used when referring to a black person (as is the case with 'nigger' in English); its use therefore constitutes a stylistic modulation involving register. Shifts also occur in the conversation between George and Candy to which we have referred in the previous section; the latter character uses a personal pronoun for 'nigger' twice in the translation (Steinbeck [1937] 2006/ Steinbeck [Čerče] 2007b, 22/24 (2x)), constituting a syntactic-semantic modification involving grammatical classes. A stylistic modulation involving register occurs in all three instances when Crooks utters 'nigger' - ćrnc, a colloquial variant of the neutral term crmec is used in the translation:

If I say something, why it's just a nigger sayin' it. [... This is just a nigger talkin, an' a bustedback nigger. (Steinbeck [1937] 2006, 80)

Če kdaj kaj rečem, pravjo, da govori samo črnc. [...] Samo črnc govori, samo pohablen črnc. (Steinbeck [Čerče] 2007b, 69)

Slovenian: "slabo dramatiziran roman o fatalni slabosti in odvisnosti človeka-poedinca."

For a more detailed overview of the reception of this novel, see Čerče (2006, 217-18).

15 Danica Čerče is an associate professor at the University of Ljubljana, where she primarily teaches Business English. She wrote her $\mathrm{PhD}$ thesis on Steinbeck and has authored numerous articles, book chapters and monographs about his work. To date, she has also translated four of Steinbeck's novels into Slovenian (SICRIS 2015).

16 Tina Mahkota was a lecturer at the University of Ljubljana until 2003, when she decided to pursue the career of a freelance literary translator. She has translated dozens of novels, children's books, plays and other texts, and has received awards for her work as a translator, including the most prestigious Slovenian award for literary translators: the Sovre Award (Sigledal 2015). 
[If I say something sometimes, they say it's just a black guy sayin' it. [...] It's just a black guy talkin', a crippled black guy.]

Similar to Gosak, in most instances Čerče uses either the adjective črnski or the noun črnc for 'colored' (Steinbeck [1937] 2006/Steinbeck [Čerče] 2007b, 80/69 (2x), 85/73, 91/77, 93/79), 'black' (Steinbeck [1937] 2006/Steinbeck [Čerče] 2007b, 77/67 (2×), 82/71) and 'negro' (Steinbeck [1937] 2006/Steinbeck [Čerče] 2007b, 75/65, 79/68). She makes two exceptions when translating the latter term. Once it is translated as temen (Steinbeck [1937] 2006/Steinbeck [Čerče] 2007b, 56/50), which means 'dark' and is not used to denote race in Slovenian; it thus represents a radical change of meaning. In the following sentence, there is a deletion of the term 'negro' from the text:

Crooks had retired into the terrible protective dignity of the negro. (Steinbeck [1937] 2006, 89) Crooks se je povlekel vase in si nadel dostojanstveni izraz [Ø]. (Steinbeck [Čerče] 2007b, 76) [Crooks retired into himself and put on a dignified expression [Ø].]

In this translation, colloquial Slovenian was used for all the characters, including Crooks, whose discourse is never expanded or shortened - the translation is integral.

In the play of the same name, Steinbeck did not preserve all the race-related discourse; thus, five instances of the term 'nigger' from the novel do not appear in the play (Steinbeck [1937] 2006/ Steinbeck [1937] 2009/Steinbeck [Mahkota] 2007a, 32/56/14, 80/122/29, 89/134/31, 91/135/31 $(2 \times))$. For all the retained instances (including those uttered by Crooks), the term zamorec is used in the translation (Steinbeck [1937] 2009/Steinbeck [Mahkota] 2007a, 38/10 (2x), 39/11 (5x), $82 / 20,122 / 29(2 \times), 160 / 37)$. As we established previously, this constitutes a stylistic modulation involving register. The noun crnec was used for the retained instances of the terms 'black' (Steinbeck [1937] 2009/Steinbeck [Mahkota] 2007a, 118/28, 119/28, 124/29), 'colored' (Steinbeck [1937] 2009/Steinbeck [Mahkota] 2007a, 128/30, 133/31) and 'negro' (Steinbeck [1937] 2009/Steinbeck [Mahkota] 2007a, 91/21), not constituting a shift. In this translation also, Crooks uses colloquial Slovenian, and his discourse is neither shortened nor expanded.

\subsubsection{Reception}

In the new millennium, the racial issues addressed in Of Mice and Men received more attention than before; they are mentioned in writings accompanying the play, although they are not discussed in depth (see Mihurko Poniž 2007, 8; Doma 2007, 13; "Ljudje in miši” 2007, 17). While there were no reviews of the retranslation of the novel, in the year before it was published its translator wrote that "the sad story of Crooks, lonely, bitter and pushed aside by the workers [...] uncovers the question of racial intolerance in all its depth"17 (Čerče 2006, 77), but racial issues are not mentioned in the metatexts about the translation strategies she used in her retranslation (see Čerče 2007, 103-6; 2011, 45-51; 2012, 191-97; Žagar 2007, 107-9).

\section{Comparison of Translation Strategies}

In our comparison of the translations, we established that there were certain differences concerning translation strategies for elements pertaining to race. The strategies regarding the racial slur 'nigger' differ most significantly. In the 1952 translation, the neutral term ćrnec was used, and thus the racist connotation of the original term was entirely neutralised. While the term zamorec, which is

Slovenian: "Žalostna zgodba osamljenega, zagrenjenega in od drugih delavcev odrinjenega delavca Crooka [...] v vsej širini odstira vprašanje rasne nestrpnosti.” 
used most frequently in both 2007 translations, is pejorative to some degree, it is not as offensive as 'nigger'. The racist connotation of this slur and its importance for the text are most evident in the confrontation between Curley's wife and Crooks, during which the former threatens the latter with lynching, and is translated as follows: ${ }^{18}$

Listen, Nigger[,] [...] [y] ou know what I can do to you if you open your trap? [...] Well, you keep your place then, Nigger. I could get you strung up on a tree so easy it ain't even funny. (Steinbeck [1937] 2006, 91)

Poslušaj me, črnec[,] [...] [m]islim, da veš, kaj ti lahko storim, če ne boš držal svojega gobca? [...] Dobro! Potem pa ostani na mestu, ki ti pripada, črnec. Dobro veš, da te lahko dam obesiti na prvo drevo; pa še užitek ne bi bil prevelik, gledati vse to, ker me ne bi stalo dosti truda, doseči, da te obesijo. (Steinbeck [Gosak] 1952, 100-101)

[Listen to me, black guy[,] [...] I think you know what I can do to you if you don't shut your trap? [...] Good! Keep the place that belongs to you then, black guy. You know very well that I can have you strung on the first tree, and it wouldn't even be a big pleasure to watch all of this, since it wouldn't take me a lot of work to have them hang you.]

Poslušej me, zamorc[,] [...] [n]ajbrž veš, kaj te čaka, če odpreš svoj klun. [...] Dober. Potem se pa obnašaj seb primerno, zamorc! Tako enostavno te lahko spravim na drevo, da me niti zabaval ne bo. (Steinbeck [Čerče] 2007b, 77-78)

[Listen to me, negro[,] [...] [y] ou probably know what awaits you if you open your trap. [...] Good. You keep your place then, negro! I could get you strung up on a tree so easy it won't even amuse me. ${ }^{19}$

In this context, the original term symbolises the daily danger faced by African Americans in the South, whereas the Slovenian terms have no threatening connotations; the term used by Gosak is not even pejorative. Since less offensive variants are used, the severity of the threat is somewhat lessened in both translations.

Further, the fact that in Čerče's translation Crooks uses the neutral term črnc in the place of 'nigger' indicates that the translator was aware of the original term's racist implication. Because Crooks uses 'nigger' only when complaining about the racism he faces (otherwise using 'black', 'colored' and 'negro'), it is evident that his vocabulary is not limited to this term only, and that its use is motivated. Therefore, it would have been important to preserve this aspect of his discourse in the translation, which neither translator of the novel has done. Several examples of shifts in Gosak's translation indicate that she also was aware of the racial issues addressed, but by constantly using the neutral term crnec, she reduced the severity of the racism; thus, readers of her translation were less likely to become aware of racial discrimination and deem it unacceptable. Furthermore, because in her translation Crooks' discourse is sometimes expanded and his language is standardised, his characterisation is altered to some degree; he plays a more important role and is more articulate than in the original.

Other characters constantly use 'nigger' when referring to Crooks, thereby indicating that racism is present and acceptable in their environment. Its use is in accordance with the social status of the characters; even before the racist connotation of 'nigger' became problematic, this term was

18 This part of the text is not included in the play (see Steinbeck [1937] 2006/Steinbeck [1937] 2009/Steinbeck [Mahkota] 2007a, 91/135/31).

19 We opted for the term 'negro' as the translation for zamorec, because both terms were neutral in the 1930s, while today they are pejorative to some degree. 
considered vulgar and was used more frequently by the lower classes, as Jabari Asim notes (2007, 28). Shifts therefore altered the characters' register, especially in the 1952 translation, since the term crnec was neutral at that time. Because in all three translations the same Slovenian term was used for 'colored', 'black' and 'negro', the differentiation of the original racial terminology is lost, thereby making the language of the characters less vivid. Since the three English terms were not offensive at the time of the original publication, and the same is true for the term crnec, these shifts do not, however, substantially affect the macrostructure of the translations, as is the case with the neutralisation of the racial slur 'nigger'.

According to her own account, Čerče set out to transpose the discourse of the original into Slovenian as faithfully as possible in her 2007 retranslation $(2011,40)$. In an effort to determine the motivation for the shifts concerning racial elements, an interview was conducted with the translator on 18 October 2012 to enquire whether she had considered using any Slovenian terms other than zamorc and if so, why she opted not to use them in the end. She answered that she perceived zamorc as pejorative, and therefore considered it as the most appropriate translation for 'nigger'. She also stated that she opted for the term črnc in all the instances when Crooks used 'nigger' because she did not want the only African American character in the novel to use racist terms when referring to himself. Through e-mail, Tina Mahkota was asked the same question, and on 5 November 2012 the following answer was received: "As far as I can remember, the word zamorec just seemed suitable in the context of Steinbeck's play. I think I never really gave much thought to using črnuh, crnuhar, etc." ${ }^{20}$

\section{Consideration of the Results in Their Historical and Ideological Context}

There are several possible reasons why the offensive terminology referring to African Americans was completely neutralised in the first translation and only partially preserved in the modern translations. The translation strategies may have been partially influenced by the role that the Slovenian language has traditionally had; it has long been seen as "one of the pillars of Slovenian identity" ${ }^{21}$ (Poniž 2002, 86), and thus there was a tendency to use standard language in literature (Hladnik 1983, 61), including in translated texts (see, for instance, Onič 2003, 400; Zlatnar Moe 2004, 223; Čerče 2012, 189; Trupej 2014a).22

Other ideological factors may have influenced the translation strategy for racial elements in the socialist period. An analysis of the contemporary commentaries related to the issues of racism in Slovenian state-regulated print has shown that in the newly established socialist system racism was seen as unacceptable (Trupej 2014b, 91-92). Furthermore, the contemporary relations between the USA and Yugoslavia might also have been a factor. As Jože Pirjevec $(2011,299-308)$ notes, while in the first post-war years there was considerable tension (even to the point of a possible military conflict) between the USA and Yugoslavia, which was backed by the USSR, relations improved greatly after the Tito-Stalin split in 1948 and Yugoslavia's subsequent expulsion from the Cominform. Because the USA was an ally of Yugoslavia at the time when Of Mice and Men was translated, this may have influenced Meta Gosak's decision to portray Americans as less racist.

\footnotetext{
20 Slovenian: "[K]olikor se spomnim, se mi je zamorec zdel pač najbolj ustrezen v kontekstu Steinbeckove drame. Mislim, da na kakega črnuha ali črnuharja itd. nisem niti kaj dosti pomislila."

21 Slovenian: "[eden] od slovenskih identitetnih stebrov."

22 Bernard Nežmah notes that vulgar terms were often even excluded from dictionaries (1997, 21-27, 71; cf. Trupej 2014c, 636-37).
} 
International relations were again substantially different when the translation of Steinbeck's Travels with Charley was published in 1963; once relations with the USSR gradually began to improve after Stalin's death, Yugoslavia again distanced itself from the Western bloc, and began to strengthen its ties with countries that later founded the Non-Aligned Movement in 1961 (Pirjevec 2011,308-20). In the translation entitled Potovanje s Charleyem Gosak used a translation strategy that differs considerably from the one she employed when translating Of Mice and Men. In the concluding chapter, where the issue of racism and segregation in the American South is addressed, the 28 instances of the term 'negro' are translated as either zamorec (Steinbeck 1962/Steinbeck [Gosak] 1963, 217/175, 218/175 (2x), 218/176 (3×), 219/176 (2×), 220/177, 222/178, 233/188, 234/188) or ćrnec (Steinbeck 1962/Steinbeck [Gosak] 1963, 216/174 (2×), 217/174 (2x), 226/182, 232/187 (2x), 233/187, 234/189, 235/189, 236/190 (2x), 236/191 (2x), 240/194). ${ }^{23}$ Both Slovenian terms are used by Steinbeck (in his role as first person narrator and in dialogue), as well as by his interlocutors, therefore the motivation for the choice of either term is not clear.

In this part of the travelogue, the term 'nigger' appears 18 times, and in all but one of these instances the term zamurc (a more pejorative variant of zamorec) is used in the translation (Steinbeck 1962/ Steinbeck [Gosak] 1963, 221/178 (2×), 222/178, 223/179 (2×), 223/180, 224/181, 238/192, $239 / 193(5 \times), 240 / 194(4 \times))$. One omission can be noted: in the original, the collocation 'niggerlover' is used three consecutive times, while in the translation it is translated only twice (Steinbeck 1962/Steinbeck [Gosak] 1963, 240/194). Because Gosak used a pejorative Slovenian term in this translation, one can presume that she was aware that different English racial terms have different connotations. The fact that by 1963 Yugoslavia's relations with the United States had somewhat cooled off again may have been the reason why this time she decided to preserve the racist terms in the translation. ${ }^{24}$

This is reminiscent of another example of different translation strategies used by the same translator for two texts in the same genre: in Pavel Holeček's 1948 translation of Adventures of Huckleberry Finn, the severity of racist discourse is increased several times (see Trupej 2012, 96101; Trupej 2014b: 98-99), while in his 1957 translation of Tom Sawyer, Detective, it is censored in two instances (see Trupej 2014b: 101). ${ }^{25}$ The first translation was published during the period of Yugoslavia's conflict with the USA, and the second was published when relations between the two states were better; this suggests that the contemporary political situation influenced how literary works were translated in Slovenia.

\section{Conclusion}

We can establish that socialist and post-socialist strategies for translating racial elements in $O f$ Mice and Men were somewhat different: the offensive terminology referring to African Americans is completely neutralised in the socialist period, while in both translations published in the postsocialist era it is preserved to some extent, but the most offensive terms for black people are avoided in those texts also. These translation strategies were possibly influenced by the traditional demand for the use of the standard Slovenian language in literature, which is linked to the unifying role that language has historically had for the Slovenian nation.

\footnotetext{
23 There is also one occurrence of the word učenec (pupil/student) (Steinbeck 1962/Steinbeck [Gosak] 1963, 234/188), but this radical change of meaning was probably an error.

24 There is a possibility that Gosak was not aware of the racist connotation when she translated OfMice and Men eleven years prior.

25 An additional factor may have been the fact that by that time the widely publicised African American Civil Rights Movement had brought international attention to the problem of racism.
} 
The decision to soften the racist discourse in the translation published in the socialist period may also have been ideologically conditioned: the socialist regime perceived racism as unacceptable, and furthermore, at the time of publication Yugoslavia was on friendly terms with the United States, which may have influenced the translator's decision to portray the characters as less racist than in the original. This claim is substantiated by the fact that in times when relations between the two states were tense, racism was preserved and sometimes even intensified in other translations.

The overview of the reception of the Slovenian Of Mice and Men translations shows that the issue of racism has not received a level of attention comparable to that in the USA. This indicates that - along with the fact that the issue at hand is less relevant to Slovenians - shifts in the translations influenced the reception of this literary work; since the racist discourse of the original is largely neutralised in the Slovenian translations, it was less likely that the racism would be perceived as problematic. We have thus shown how translation strategies for racist discourse can affect the perception and consequently the reception of a literary work. Therefore, this article may be of use to literary translators dealing with racial elements, and can also be a starting point for further research on related issues.

\section{References}

Asim, Jabari. 2007. The N Word: Who Can Say It, Who Shouldn't, and Why. Boston: Houghton Mifflin.

b. 1952. "Novi zvezki Male knjižice." Ljubljanski dnevnik, February 2.

Battistella, Edwin L. 2005. Bad Language: Are Some Words Better than Others? New York: Oxford University Press.

COBISS. Kooperativni online bibliografski sistem in servisi Online 2015. Accessed March 28, 2015. http:// www.cobiss.si/.

Čerče, Danica. 2006. Pripovednistvo Johna Steinbecka. Maribor: Mariborska literarna družba.

—. 2007. "O razumevanju Steinbeckovega romana $O$ miših in ljudeh." Afterword to $O$ miših in ljudeh by John Steinbeck, 103-6. Maribor: Mariborska literarna družba.

—. 2011. Reading Steinbeck in Eastern Europe. Lanham: University Press of America.

—. 2012. “(Ne)prevedljivost pogovornega jezika v delih Johna Steinbecka." Slavistična revija 60 (2): 185-98. Accessed March 28, 2015. http://www.srl.si/sql pdf/SRL 20122 04.pdf.

Bakker, Matthijs, Cees Koster, and Kitty van Leuven-Zwart. 2009. "Shifts." In Routledge Encyclopedia of Translation Studies, 2nd ed., edited by Mona Baker and Gabriela Saldanha, 269-74. London: Routledge.

Digital Library of Slovenia. 2014. http://www.dlib.si.

Doma, Tatjana. 2007. “Človek na konju je duhovno, prav tako kot fizično, večji od tistega, ki pešači." Gledališki list Slovenskega ljudskega gledališca Celje 57 (6): 11-14.

Flere, Djurdjica. 1948. "Po vojni v pariških dramskih gledališčih.” Novi svet 3 (11): 876-81.

Foerstel, Herbert N. 2002. Banned in the U.S.A.: A Reference Guide to Book Censorship in Schools and Public Libraries. Westport: Greenwood Press.

G. K. 1938. "Angleški roman v preteklem letu." Jutro, February 2.

Gabrič, Aleš. 2000. “Predolga pot do prvega slovenskega zakona o knjižnicah iz leta 1961.” Knjižnica 44 (3): 31-54.

Hermans, Theo. 1999. Translation in Systems: Descriptive and System-Oriented Approaches Explained. Manchester: St. Jerome Publishing.

Hill, Jane H. 2008. The Everyday Language of White Racism. Malden: Wiley-Blackwell. 
Hinds, Maurene J. 2008. John Steinbeck: Banned, Challenged, and Censored. Berkeley Heights: Enslow Publishers.

Hladnik, Miran. 1983. Trivialna literatura. Ljubljana: DZS.

"Izlet iz Gorice v Tržaško okolico." 1885. Slovenec, June 11.

"John Ernst Steinbeck: Ljudje in miši." 1952. Primorski dnevnik, February 13.

Kennedy, Randall. 2003. Nigger: The Strange Career of a Troublesome Word. New York: Vintage Books. First published 2002.

Kocijančič Pokorn, Nike. 2008. “(Post)communist Censorship in Translation - Religion as a Taboo.” In Tradition versus Modernity: From the Classic Period of the Prague School to Translation Studies at the Beginning of the 21st Century, edited by Jana Kralova and Zuzana Jettmarova, 175-85. Prague: Univerzita Karlova v Praze, Filozofická fakulta.

—. 2010. "A World without God: Slovene Bambi." In Why Translation Studies Matters, edited by Daniel Gile, Gyde Hansen, and Nike Kocijančič Pokorn, 57-68. Amsterdam: John Benjamins.

—. 2012. Post-Socialist Translation Practices: Ideological Struggle in Children's Literature. Amsterdam: John Benjamins.

Lambert, José, and Hendrik van Gorp. 2006. "On Describing Translations.” In Functional Approaches to Culture and Translation. Selected Papers by José Lambert, edited by Dirk Delabastita, Lieven D’Hulst, and Reine Meylaerts, 37-47. Amsterdam: John Benjamins. First published 1985.

Lefevere, André. 1992. Translation, Rewriting and the Manipulation of Literary Fame. London: Routledge.

"Ljudje in miši." 2007. Gledališki list SLG Celje 57:16-17.

"Mala knjižica." 1951. Slovenski knjižni trg 4 (12): 303.

Malmkjaer, Kirsten. 2004. "Censorship or Error: Mary Howitt and a Problem in Descriptive TS." In Claims, Changes, and Challenges in Translation Studies, edited by Gyde Hansen, Kirsten Malmkjaer, and Daniel Gile, 141-56. Amsterdam: John Benjamins.

Mazi-Leskovar, Darja. 2011. Mladinska proza na tej in oni strani Atlantika. Maribor: Mednarodna založba Oddelka za slovanske jezike in književnosti, Filozofska fakulteta, Univerza v Mariboru.

Meyer, Michael J. 2006a. “'Lifeboat' (Script-Novel).” In A John Steinbeck Encyclopedia, edited by Brian Railsback and Michael J. Meyer, 212. Westport: Greenwood Press.

—. 2006b. "Atque Vale." In A John Steinbeck Encyclopedia, edited by Brian Railsback and Michael J. Meyer, 17. Westport: Greenwood Press.

Mihurko Poniž, Katja. 2007. "Si moški ali si mišs?" Gledališki list Slovenskega ljudskega gledališča Celje 57 (6): 5-10.

“"Miši in ljudje’ in še kaj.” 1948. Celjski tednik, March 26.

“Narodski običaji v Železnikah.” 1854. Slovenski prijatel, March 28.

Nežmah, Bernard. 1997. Kletvice in psovke. Ljubljana: Nova revija.

“Novosti našega knjižnega trga." 1952. Ljudska pravica, February 9.

Of Mice and Men. 1939. Directed by Lewis Milestone. Hal Roach Studios.

Onič, Tomaž. 2003. "Problematika prevajanja komičnega v dramskih besedilih, specifika iger Harolda Pinterja." Vestnik 37 (1-2): 391-405.

Orel Kos, Silvana. 2001. "Let divjih labodov med nebesi in peklom: pravljica Divji labodi H. C. Andersena v slovenskih prevodih." In Prevajanje Prěserna: 26. prevajalski zbornik, edited by Martina Ožbot, 289-309. Ljubljana: Društvo slovenskih književnih prevajalcev.

Ouderkirk, Bruce. 2006. “Black Man's Ironic Burden.” In A John Steinbeck Encyclopedia, edited by Brian 
Railsback and Michael J. Meyer, 29-30. Westport: Greenwood Press.

Pirjevec, Jože. 2011. Tito in tovariši. Ljubljana: Cankarjeva založba.

Pleteršnik, Maks. 1894. Slovensko-nemški slovar. Ljubljana: Knezoškofijstvo.

Pogačnik, Jože. 1981. “Črni zamorec v Prešernovi baladi o Lepi Vidi.” Jezik in slovstvo 26 (5): 171-75.

Poniž, Denis. 2002. “1920-1929.” In Beseda se vzdiguje v dim: stoletje slovenske lirike 1900-2000, edited by Denis Poniž, 75-99. Ljubljana: Cankarjeva založba.

Prešern, Janja, 2001. "Muri, murček, zamurček: Katere besede so rasistične?” Mladina, August 21. Accessed January 7, 2015. http://www.mladina.si $/ 88037 / \mathrm{m}$-zamurc/?utm source=tednik\%2F200133\%2Fclanek\%2 Fm-zamurc\%2F\&utm medium=web\&utm campaign=oldLink.

Rattansi, Ali. 2007. Racism: A Very Short Introduction. Oxford: Oxford University Press.

SICRIS. 2015. "Danica Čerče.” Accessed March 28, 2015. http://sicris.izum.si/search/rsr. aspx?lang=slv\&id $=18111$.

Sigledal. 2015. “Tina Mahkota.” Accessed March 28, 2015. http://www.sigledal.org/geslo/Tina Mahkota.

Skušek, Ivan. 1952. “Steinbeck: Ljudje in miši.” Ljudska pravica, March 8.

Sova, Dawn B. 2006. Banned Books: Literature Suppressed on Social Grounds, rev. ed. New York: Facts on File.

Svetina, Peter. 2009. “Cenzura v prevodih mladinske književnosti v času socializma." In Odprta okna: komparativistika in prevajalstvo: Majdi Stanovnik ob 75. rojstnem dnevu, edited by Martina Ožbot, Darko Dolinar, and Tone Smolej, 263-76. Ljubljana: Društvo slovenskih književnih prevajalcev.

Steinbeck, John. 1952. Ljudje in miši. Translated by Meta Gosak. Ljubljana: Slovenski knjižni zavod.

—. 1962. Travels with Charley: In Search of America. New York: Viking Press.

—. 1963. Potovanjes Charleyem. Translated by Meta Gosak. Ljubljana: Državna založba Slovenije.

—. 2006. Of Mice and Men. London: Penguin.

—. 2007a. Ljudje in miši. Translated by Tina Mahkota. Gledališki list Slovenskega ljudskega gledališča Celje 57 (6): $1-40$.

—. 2007b. O miših in ljudeh. Translated by Danica Čerče. Maribor: Mariborska literarna družba.

-. 2009. Of Mice and Men: A Play in Three Acts. London: Penguin Books.

Trupej, Janko. 2012. “Translating Racist Discourse in Slovenia during the Socialist Period: Mark Twain's Adventures of Huckleberry Finn." In Translation and the Reconfiguration of Power Relations: Revisiting Role and Context of Translation and Interpreting, edited by Beatrice Fischer and Matilde Nisbeth Jensen, 91-107. Berlin: LIT Verlag. Accessed March 28, 2015. http://www2.arts.kuleuven.be/info/bestanden-div/ Translation $\% 20$ and $\% 20$ the $\% 20$ reconfiguration $\% 20 \mathrm{of} \% 20$ power $\% 20$ relations.pdf.

—. 2013. "Slovensko prevajanje rasističnega diskurza o Afroameričanih v ameriških romanih." PhD diss., University of Ljubljana.

—. 2014a: "Cenzura profanosti pri podnaslavljanju." In Znanstveno srečanje doktorskih študentov, Ljubljana, 6. december 2013, edited by Maruška Agrež, 41-48. Ljubljana: Zveza društev Slavistično društvo Slovenije. Accessed March 28, 2015. http://641.gvs.arnes.si/zsds kv.pdf.

—. 2014b. "Prevajanje rasističnega diskurza o temnopoltih v slovenščino." Primerjalna književnost 37 (3): 89-109.

—. 2014c. "Zaznamovanost slovenskega izrazoslovja za temnopolte." Slavistična revija 62 (4): 635-45. Accessed March 28, 2015. http://www.srl.si/sql pdf/SRL 2014_4_12.pdf. 
van Leuven-Zwart, Kitty. 1989. “Translation and Original: Similarities and Dissimilarities, I.” Target 1 (2): $151-81$.

—. 1990. "Translation and Original: Similarities and Dissimilarities, II." Target 2 (1): 69-95.

Venuti, Lawrence. 1998. The Scandals of Translation. London: Routledge.

Werlock, Abby H. P. 2006. "Vigilante, The." In A John Steinbeck Encyclopedia, edited by Brian Railsback and Michael J. Meyer, 408-9. Westport: Greenwood Press.

Zlatnar Moe, Marija, 2004. "Odstrani, prosim, prste mi z vratu: Prevajalske norme v dramskih prevodih 20. stoletja.” Vestnik 38 (1-2): 207-27.

Žagar, France. 2007. "Pogovornost v izvirniku in prevodu našega romana." Afterword to $O$ miših in ljudeh by John Steinbeck, 107-9. Maribor: Mariborska literarna družba. 